\title{
Proses Penyelesaian Sengketa Pembagian Kasus Harta Gono Gini Akibat Perceraian Pasangan Suami Istri di Pengadilan Agama Mataram
}

\author{
Zedi Muttaqin', Siti Urwatul Usqak²
}

\footnotetext{
${ }^{1}$ Pendidikan Pancasila dan Kewarganegaraan, Universitas Muhammadiyah Mataram, zedi.muttaqien84@gmail.com

${ }^{2}$ Pendidikan Pancasila dan Kewarganegaraan, Universitas Muhammadiyah Mataram, sitiurwatulusqak27932@gmail.com
}

INFO ARTIKEL
Riwayat Artikel:
Diterima: 18 September
2020
Disetujui: 30 September
2020

Kata Kunci:

Sengketa

Pembagian

Harta Gono-Gini

Perceraian

\begin{abstract}
ABSTRAK
Abstrak: Tujuan penelitian ini adalah untuk mengetahui tugas dan peran pengadilan agama dalam menyelesaikan kasus harta gono gini sebagai upaya penyelesaian konflik keluarga pasca bercerai suami dan istri (studi kasus di Pengadilan Agama Mataram). Penelitian ini adalah penelitian kualitatif dengan pendekataan deskriptif. Subyek penelitian atau informan dalam penelitian ini adalah Kepala Pengadilan Agama, Hakim, dan Panitera Pengadilan Agama Mataram. Metode pengumpulan data yang digunakan adalah Observasi, wawancara dan dokumentasi. Sumber data yang digunakan yaitu sumber data primer, Teknik analisis data adalah reduksi data, penyajian data, dan menarik kesimpulan. Hasil penelitian yang diperoleh bahwa tugas dan peran pengadilan agama mataram dalam menyelesaikan kasus harta gono gini yaitu : Tugas dan Peran Pengadilan Agama Mataram yaitu menerima, memeriksa, memutuskan, mengadili dan menyelesaikan perkara yang diaajukan oleh para pihak penggugat., dan Proses penyelesaian dan pertimbangan hakim dalam menentukan pembagian harta gono gini yaitu : Hakim dalam proses pembagian harta bersama yaitu membagi harta bersama tersebut sama-sama $1 / 2$ (seperdua) penggugat dan tergugat sedangkan hakim dalam mempertimbangkan pembagian harta gono gini atau harta bersama tidak mesti terpaku terhadap UU tetapi sebagai hakim proses pertimbangan pembagian harta gono gini harus berdasarkan rasa keadilan karna hakim sendiri mempunyai asas kontralegen.
\end{abstract}

\begin{abstract}
The purpose of this study was to determine the duties and roles of religious courts in resolving inheritance cases as an effort to resolve family conflicts after divorce (a case study at the Mataram Religious Court). This research is qualitative research with a descriptive approach. The research subjects of the study were the Head of the Religious Courts, Judges, and Registrars of the Mataram Religious Court. Data collection methods used were observation, interviews, and documentation. Sources of data used were primary data sources; data analysis techniques were data reduction, data presentation, and concluding. The results showed that the duties and roles of the Mataram Religious Court in resolving the case of the Mataram Religious Court are the Duties and Roles of the Mataram Religious Court such as receiving, examining, deciding, adjudicating and completing cases filed by the plaintiffs, and the process of settlement and judges' considerations. In determining the distribution of assets of inheritance, the judges in the process of sharing joint assets are dividing the joint assets together $1 / 2$ (half) of the plaintiff and the defendant, while the judge in considering the distribution of assets or joint assets does not have to be fixated on the law but as a judge in consideringthe process of the distribution of assets must be based on a sense of justice because the judges themselves have theprinciple of contralegem.
\end{abstract}

\section{A. LATAR BELAKANG}

Ikatan perkawinan menjadikan adanya harta bersama suami istri, sebagaimana pengertian harta gono gini dalam UU No. 1 Tahun 1974 Tentang Perkawinan dalam Pasal 35 UU No. 1 Tahun 1974 Mengatakan bahwa harta benda yang diperoleh selama perkawinan menjadi harta bersama, harta bawaan dari masing-masing suami dan istri dan harta benda yang diperoleh masing-masing sebagai hadiah atau warisan adalah dibawah penguasaan masing-masing sepanjang para pihak tidak menentukan lainnya.[1];[2]

Pembagian harta gono gini pasca perceraian suami istri telah banyak yang melakukan penelitian, beberapa penelitian tersebut menemukan berbagai ragam aspek, secara yuridis normatif menghasilkan Pertama, apabila perkawinan putus karena perceraian, maka harta bersama atau harta gono-gini diatur menurut hukumnya masing-masing. Kedua, pentingnya perjanjian perkawinan dibuat agar supaya membatasi atau 
meniadakan sama sekali kebersamaan harta kekayaan menurut undang-undang perkawinan.[3] Demikian juga lainnya menemukan Pertama, pembagian harta gonogini akibat perceraian berdasarkan ketentuan Pasal 36 Undang-undang Perkawinan, suami istri dapat bertindak atas persetujuan kedua belah pihak melalui musyawrah kesepakatan dan kerelaan kedua belah pihak, untuk dapat dibagi dua karena kedudukan suami dan istri seimbang dalam perkawinan atau pembagian lain sesuai kesepakatan. Kedua, penetapan hak asuh anak akibat perceraian menurut Inpres Nomor 1 Tahun 1991, untuk anak yang belum dewasa atau belum berumur 12 (dua belas) tahun adalah hak ibunya. Sedangkan untuk anak yang sudah dewasa diserahkan kepada anak untuk memilih di antara ayah dan ibunya sebagai pemegang hak anaknya.[4] Harta gono gini itu di atur dalam Undang-undang no 1 tahun 1974 tentang perkawinan bab VII tentang harta benda dalam perkawinan pasal 35, Kitab Undang-undang Hukum Perdata pasal 119 dan Kompilasi Islam pasal 85.[5]

Pembagian harta bersama dalam perkawinan dilakukan setelah ada putusan perceraian. Menurut KHI berdasarkan pada Pasal 97 harta bersama setelah perceraian dibagi rata, masing-masing $1 / 2$ bagian antara suami dan isteri sama. Sedangkan menurut KUHPerdata pembagian dapat dilakukan atas bukti-bukti yang diajukan oleh penggugat dan tergugat. Dasar pertimbangan hakim dalam memutuskan perkara pembagian harta bersama menurut KHI ada dua yaitu dasar musyawarah dan keadilan.[6] Tugas dan peran pengadilan agama dalam menyelesaikan kasus harta gono gini yaitu: menerima, memeriksa, memutuskan, mengadili dan menyelesaikan perkara yang diaajukan oleh para pihak penggugat. Hakim dalam proses pembagian harta bersama yaitu membagi harta bersama tersebut sama-sama $1 / 2$ (seperdua) penggugat dan tergugat sedangkan hakim dalam mempertimbangkan pembagian harta gono gini atau harta bersama tidak mesti terpaku terhadap Undang-Undang tetapi sebagai hakim proses pertimbangan pembagian harta gono gini harus berdasarkan rasa keadilan karna hakim sendiri mempunyai asas kontralegen.[7]

Berbagai temuan penelitian sebelumnya lebih membahas aspek yuridis normative dalam pembagian harta gono gini pada suami istri setelah perceraian, penetapan hak asuh anak pasca perceraian, pembagian harta gono-gini menurut ketentuan hukum Islam dan ketentuan hukum perdata, hakim mempertimbangkan pembagian harta gono-gini pasca perceraian. Sedangkan aspek proses penyelesaian sengketa harta gono-gini suami-istri pasca perceraian belum banyak yang meneliti, aspek persamaan dengan penelitian sebelumnya terletak pada harta gono-gini suami istri setelah perceraian, kemudian letak perbedaannya juga pada lokasi dan objek penelitian. Pada penelitian kualittaif ini harta gono-gini ini dikemas secara komprehensif dan substasi pada sengketa harta gono-gini suami istri pasca cerai dapat di selesaikan secara baik, musyawarah dan undang-undang yang berlaku. Penyelesaian sengketa harta gono-gini suami istri pasca cerai harus diselesaikan di pengadilan agama dan dimediasi oleh hakim pengadilan agama mulai proses, pembuktian sampai pembagian harta gono-gini yang sah secara hukum agama dan hukum perdata.

Proses penyelesaian sengketa pembagian harta gono-gini suami istri pasca cerai dilakukan dengan meliputi tahap menerima, memeriksa, memutuskan, mengadili dan menyelesaikan perkara yang diaajukan oleh para pihak penggugat terhadap tergugat, dengan proses pembagian harta gono gini tersebut dibagi samasama $1 / 2$ (seperdua) suami dan $1 / 2$ (seperdua) istri. Pembagian harta gono-gini berdasarkan hukum positif dan berdasarkan perjanjian kedua pihak dalam perkawinan.[8] Dalam hal proses penyelesaian sengketa harta bersama dalam perkara perceraian dijalankan di Pengadilan Negeri, menurut hukum acara perdata bahwa diajukan terlebih dahulu gugatan perceraian, setelah diputus dan memiliki kekuatan hukum tetap barulah diajukan gugatan harta bersama (gono gini). Serta dalam pengajuan gugatan harta bersama hutang harus dimasukkan dalam gugatan guna pertimbangan hakim dalam gugatan. Pertimbangan Hakim dalam memberikan putusan perkara penyelesaian sengketa harta bersama dalam perkara perceraian di Pengadilan Negeri, yaitu pembuktian dalam hal apakah benar ada harta bersama dalam perkawinan, kapan waktu harta tersebut diperoleh oleh suami atau istri, apakah sebelum perkawinan atau sesudah perkawinan.[9]

Harta gono gini suami istri dalam Pasal 35 Ayat (1) UU No. 1 Tahun 1974 Tentang Perkawinan bahwa harta benda yang diperoleh selama perkawinan menjadi harta bersama, mengandung arti bahwa harta yang diperoleh selama batas waktu antara saat perkawinan diresmikan sampai perkawinan terputus baik terputus karena kematian salah seorang diantara suami istri (cerai mati) maupun putus karena perceraian (cerai hidup) menjadi harta bersama.[10]

Pembagian harta gono gini diatur menurut hukum yang tercantum dalam Pasal 37 UU No. 1 Tahun 1974 Tentang Perkawinan yaitu sebagai berikut: bila perkawinan putus karena perceraian harta bersama diatur menurut hukumnya masing-masing. Dari bunyi Pasal di atas yang dimaksud hukumnya masing-masing menurut penjelasan Pasal 37 UU No. 1 Tahun 1974 tentang perkawinan adalah hukum masing-masing suami istri yang melangsungkan perkawinan yaitu menunjuk pada hukum agama, hukum adat dan hukumhukum lainnya.[10]

Sebagaimana pemisahan harta gono gini apabila terjadi perceraian diantara keduanya, maka dapat diajukan ke Pengadilan Agama untuk diperiksa oleh Hakim, untuk melindungi pihak ketiga. Keputusan 
hakim mengakibatkan seorang istri mendapat haknya tentang hak bersama, apabila perkawinan sudah putus. Dan pemisahan harta gono gini dapat dilakukan dengan perjanjian atau persetujuan dalam akta notaris yang harus diumumkan dengan cara yang sama sebagai mana keputusan seorang hakim dalam mengadakan pemisahan pembagian harta bersama.

Realita yang terjadi saat ini, tingkat perceraian di kota Mataram sudah banyak kita dengar, bahkan tingkat perceraian sudah banyak dimasuki oleh kalangan remaja sehingga perceraian di kota Mataram semakin meningkat. Tingginya angka perceraian di Nusa Tenggara Barat (NTB) merupakan permasalahan yang harus segera diatasi. Tingkat perceraian di Nusa Tenggara Barat (NTB) ini sudah mencapai dibawah rata-rata Nasional yakni 58 Persen sedangkan nasional 60 persen.

Berdasarkan hasil data Pengadilan Agama Mataram bahwa Tingginya angka perceraian tersebut membuat perempuan berstatus janda dan laki-laki menjadi duda banyak terdapat di Nusa Tenggara Barat (NTB) dengan angka mencapai 21 persen. Mengapa tingkat perceraian di Nusa Tenggara Barat (NTB) tinggi, karena memang perkawinan di usia muda cukup banyak. Rata-rata usiaperkawinan di NTB berumur 19 Tahun kebawah. Bahkan ditingkat Nasional Provinsi masuk dalam 1 (satu) besar daerah yang tinggi angka perceraiannya. [11]

Apabila perceraian terjadi sudah dapat dipastikan akan menimbulkan dampak hukum dan dampak sosial. Dampak hukumnya akan mengakibatkan putusnya ikatan perkawinan yang sah menurut Undang-undang pernikahan sedangkan dampak sosialnya akan mengakibatkan terlantarnya anak dari hasil perkawinan dan perebutan hak asuh serta harta didalam semenjak perkawinan. Sebagaimana diketahui bahwa adanya harta bersama dalam perkawinan tidak menutup kemungkinan adanya harta milik masing-masing suami istri. Harta bersama tersebut dapat berupa benda tidak bergerak, benda bergerak dan surat-surat berharga. Sedangkan yang tidak berwujud bisa berupa hak atau kewajiban suami kepada istri.

Untuk itu, artikel ini berusaha menjelaskan proses penyelesaian sengketa pembagian kasus harta gono gini akibat perceraian pasangan suami istri secara yuridis normative. Tujuan artikel ini untuk menguraikan proses penyelesaian sengketa pembagian kasus harta gono gini akibat perceraian pasangan suami istri. Proses penyelesaian ini meliputi tahap menerima, memeriksa, memutuskan, mengadili dan menyelesaikan perkara yang diaajukan oleh para pihak penggugat terhadap tergugat, serta peran hakim dalam menyelesaikan sengketa harta gono-gini dengan mengedepankan asas pemanfaatan, kepastian, dan keadilan.

\section{B. METODE PENELITIAN}

1. Metode dan pendekatan penelitian
Metode penelitian merupakan suatu cara untuk memecahkan suatu masalah yang sedang dihadapi, demikian juga dengan penelitian ini diperlukan metode yang tepat untuk memecahkan masalah yang akan di teliti. Untuk menyelesaikan karya ilmiah ini, Penulis menggunakan metode kualitatif dengan pendekatan deskriptif.

Pendekatan deskriptif digunakan untuk menganalisis dan menggambarkan proses penyelesaian kasus harta gono gini sebagai upaya penyelesaian konflik keluarga pasca bercerai suami istri di Pengadilan Agama Mataram.

2. Subjek Penelitian

Informan penelitian ini adalah Ketua Pengadilan Agama, Hakim, Panitera Pengadilan Agama dan Masyarakat yang terlibat dalam kasus harta gono gini.

3. Sumber Data Penelitian

Sumber data primer merupkan sumber data yang diperoleh secara langsung dari informan di lapangan yaitu melalui wawancara mendalam (indept interview) dipergunakan untuk memperoleh data dengan metode wawancara dengan narasumber yang akan diwawancarai. Sumber data sekunder merupakan sumber data yang diperoleh secara tidak langsung dari informan dilapangan, misalnya lewat orang lain, dokumen, arsiparsip, publikasi dan artikel mengenai masalah yang diteliti.

4. Teknik Pengumpulan Data

Teknik pengumpulan data yang digunakan dalam penelitian ini adalah teknik observasi, wawancara dan dokumentasi.

5. Teknik Analisis Data

Setelah diperoleh dan dikumpulkan maka dilakukan analisis data dengan cara kualitatif. Dimana data yang diperoleh dilapangan akan direduksi, disajikan dan kemudian ditarik kesimpulan.

\section{HASIL DAN PEMBAHASAN}

\section{Tugas Pengadilan Agama}

Adapun hasil uraian penulis tentang Tugas Pengadilan Agama Mataram dalam menyelesaikan kasus harta gono gini sebagai upaya penyelesaian konflik keluarga pasca bercerai suami dan istri sebagai berikut:

Tugas Hakim di Pengadilan Agama Mataram yaitu, sebagaimana dijelaskan dalam Pasal 49 Undang-undang No. 50 Tahun 2010 Tentang Pengadilan Agama. Pengadilan agama merupakan pengadilan ditingkat pertama yang bertugas sebagai memeriksa, memutuskan, dan menyelesaikan perkara-perkara ditingkat pertama antara orang-orang yang beragama islam dibidang perkawinan, kewarisan, wasiat dan hibah yang dilakukan berdasarkan hukum islam, serta wakaf dan shadaqah.

"Tugas dari Hakimitu sendiri adalah menerima, memeriksa, memutuskan, mengadili dan menyelesaikan perkara yang diajukan oleh para 
pihak penggugat". (wawancara Hakim Pengadilan

Agama Mataram Tanggal 15 Juni 2020).

Tugas Panitera di Pengadilan Agama Mataram yaitu sebagaimana dijelaskan dalamUndang-undang No. 3 Tahun 2006 Tentang Perubahan atas Undang-undang No. 70 Tahun 1989 Peradilan Agama. Secara umum, panitera sebagai pelaksana administrasi pengadilan memiliki tiga macam tugas panitera, pelaksana administrasi perkara, pendamping hakim dalam persidangan dan pelaksana putusan/penetapan pengadilan serta tugas-tugas kejurusitaan lainnya. Sebagai pelaksana administrasi perkara, panitera berkewajiban tugas dari para pembantunya, yaitu panitera muda dan panitera pengganti. Sebagai pendamping hakim/ majelis dalam persidangan panitera berkewajiban mencatat jalannya persidangan dan dari catatan-catatan tersebut perlu disiapkan berita acara persidangan. "Tugas Panitera itu sendiri yaituuntuk melaksanakan administrasi perkara, dan untuk mencatat jalanannya persidangan sampai proses jalan persidangan berakhir". (wawancara Panitera Pengadilan Agama Mataram, Tanggal 4 Juni 2020).

\section{Proses Penyelesaian Sengketa Pembagian Kasus Harta Gono Gini Akibat Perceraian pasangan suami istri diPengadilan Agama Mataram}

Sebagaimana kita ketahui bahwa di dalam hukum positif yang berlaku di Indonesia, harta gono gini atau harta bersama diatur didalam Pasal 35 UU No. 1 Tahun 1974 Tentang Perkawinan, Pasal 119 KUH Perdata, Pasal 85 dan 86 Kompilasi Hukum Islam. Pengaturan harta gono gini atau harta bersama diakui secara hukum, baik secara kepengurusan, penggunaannya serta pembagiannya. Ketentuan harta gono gini atau harta bersama juga di atur dalam hukum islam meskipun hanya bersifat umum dan tidak diakui pencampuran harta kekayaan suami istri, namun setelah diamati dan dianalisis yang tidak bisa di campur adalah harta bawaan dan harta perolehan. Hal ini sesuai dengan ketentuan yang berlaku didalam hukum positif, bahwa kedua macam harta itu (harta bawaan dan harta perolehan) harus terpisah dari harta gono gini itu sendiri.

Penyelesaian sengketa yang terjadi terhadap kedua pasangan suami dan istri karena perbedaan pendapat diantara kedua belah pihak karena harta juga dapat mengacu pertikaian. Sehingga atas hal inilah terjadi suatu ketidakseimbangan kepemilikan dan diperlukan adanya suatu kebijakan untuk menyertakan kedudukan bagi kedua belah pihak.

Tentunya dari para kedua belah pihak tidak ada yang ingin bersengketa yang menimpa dirinya akan mempengaruhi perkawinannya dan merugikan pihaknya dalam segi pembagian harta gono gini atau harta bersama. Oleh karena itu dari kedua belah pihak tentunya mengharapkan suatu penyelesaian yang adil dan aturan-aturan hukum yang jelas dalam menyelesaikan sengketa yang melibatkan harta tersebut.

$$
\begin{gathered}
\text { PUTUSAN } \\
\text { NOMOR 177/Pdt.G/2019/PA.Mtr. }
\end{gathered}
$$

DEMI KEADILAN BERDASARKAN KETUHANAN YANG MAHA ESA

Pengadilan Agama Mataram yang memeriksa dan mengadili perkara tertentu pada tingkat pertama dalam sidang majelis telah menjatuhkan putusan perkara harta bersama antara lain:

Penggugat, lahir pada tanggal 14 Maret 1966, Agama Islam, Pekerjaan Mengurus rumah tangga, Pendidikan SMA, bertempat tinggal di kelurahan Pagesangan Barat Kecamatan Mataram, Kota Mataram, Berdasarkan surat kuasa khusus Nomor : A.01/14/Hasibuan \& Partners/III/2019, tanggal 18 Maret 2019 dalam hal ini memberikan kuasa kepada 1. Albert Evans Hasibuan, S.H, 2. Satrio Edi Suryo, S.H.M.H, 3. Robby Akhmad Surya Dilaga, S.H.M.H, 4. Muhammad Rosikhu, S.H, 5 . Sukriawan Saemurdani, S.H, 6. Suntarajaya Kwangtama Tekayadi, S.H.M.H, kesemuanya, Advokat pada kantor "HASIBUAN \&PARTNERS" yang beralamat jalan Ragi Genap No. 7 Ampenan Kota Mataram, sebagai penggugat;

Melawan

Tergugat, lahir pada tanggal 29 januari 1960, Agama Islam, Pendidikan S1, Pekerjaan Pegawai Negeri Sipil, bertempat tinggal di Kelurahan Pagesangan Barat Kecamatan Mataram, Kota Mataram, Berdasarkan surat kuasa khusus, Nomor : 069/SK.PDT/ADV.IS/IS.P/IV/2019, tanggal 8 April 2019, dalam hal ini memberikan surat kuasa kepada : 1 . Iskandar, S.H.M.H.C.L.A, C.H, 2. Sri Putri Indrawati, S.H, 3. Sahrul, S.H.M.H, kesemuanya, Advokat/Auditor Hukum/Konsultan Hukum pada kantor ADVOKAT \& AUDITOR HUKUM \& PARTNERS beralamat di Graha Dekipiwil NTB Lt.2 Jalan Bung Karno No. 30 Mataram Provinsi NTB, sebagai tergugat;

Pengadilan Agama tersebut; Telah mempelajari surat-surat yang berkaitan dengan perkara ini; Telah mendengar keterangan kuasa penggugat dan kuasa hukum tergugat serta para saksi di muka sidang;

\section{Duduk Perkara}

Menimbang, bahwa penggugat dalam surat gugatannya, tanggal 18 Maret 2019 telah mengajukan gugatan harta bersama yang telah terdaftar di Kepaniteraan Pengadilan Agama, dengan Nomor 177/Pdt.G/2019/PA.Mtr., tanggal 20 Maret 2019, dengan perubahan dan perbaikan yang dalil-dalil sebagai berikut :

1) Bahwa penggugat dan tergugat adalah suami istri yang telah bercerai secara resmi di Pengadilan Agama Mataram sesuai dengan putusan Pengadilan 
Agama Mataram, No: 445/Pdt.G/2018/PA.Mtr tanggal 24 September 2018 yang telah berkekuatan hukum dan telah dikeluarkan akta cerai No: 502/AC/2009/PA.Mtr, tertanggal 10 Oktober 2018

2) Bahwa selama penggugat dan tergugat terikat perkawinan, telah dikaruniai 3 (tiga) orang anak, masing-masing :

a. Anak pertama perempuan, lahir di Mataram pada tanggal 20 November 1989 (umur 29 tahun);

b. Anak kedua perempuan, lahir di Mataram pada tanggal 1 Agustus 1992 (umur 26 tahun);

c. Anak ketiga laki-laki, lahir di Mataram pada tanggal 12 Desember 2000 (umur 18 tahun);

3) Bahwa penggugat dan tergugat bercerai secara resmi di Pengadilan Agama Mataram sesuai dengan putusan Pengadilan Agama Mataram, No. 445/Pdt.G/2018/PA.Mtr, tanggal 24 September 2018 dan telah dikeluarkan Akta cerai No. 502/AC/2018/PA.Mtr, tanggal 10 Oktober 2018 ;

4) Bahwa Sembilan bulan sebelum bercerai, penggugat meninggalkan tempat kediaman bersama tanpa membawa apa-apa dan semenjak itu juga penggugat berusaha bertahan hidup dengan semampunya bersama saudara penggugat, hal ini dikarenakan penggugat yang haya seorang ibu rumah tangga, berbeda dengan penggugat yang berstatus Pegawai Negeri Sipil yang mampu bertahan hidup karena memiliki pekerjaan yang layak;

5) Bahwa selama masa berlangsungnya perkawinan antara penggugat dan tergugat telah diperoleh harta bersama berupa :

(1) Tanah beserta bangunan dengan Sertifikat Hak Milik (SHM) atas nama tergugat yang terletak di kelurahan Pagesangan Barat Kecamatan Mataram, Kota Mataram, dengan batas-batas :

Sebelah Utara : Bapak Fahrudin

Sebelah Barat : Jalan/Bapak H. Taufik

Sebelah Selatan : Ibu Ida Azis

Sebelah Timur : Jalan/ Gang

(2) 1 (satu) unit kendaraan roda empat merk Toyota Kijang Super KF 40 Short tahun 1992 atas nama tergugat dengan Nomor Polisi DR 1340 WZ berwarna hitam,

(3) 1 (satu) unit kendaraan roda dua merek Honda Vario 125 type Honda $\mathrm{NC} 12 \mathrm{~A} 1 \mathrm{CF} \mathrm{A} / \mathrm{T}$ atas nama Tergugat dengan Nomor Polisi DR 5075 CG berwarna hitam,

(4) 1 (satu) unit kendaraan roda dua merek Honda Beat type NC $11 \mathrm{BIC} \mathrm{A} / \mathrm{T}$ atas nama Tergugat dengan Nomor Polisi DR 6120 BI warna hitam,

Adalah harta bersama yang diperoleh penggugat dan tergugat selama perkawinan;

6) Bahwa harta bersama tersebut di atas sejak perceraian sampai dengan diajukannya gugatan ini masih dalam pengusaan tergugat, walaupun telah beberapa kali penggugat peringkat tergugat agar terhadap harta bersama tersebut dibagi 2 (dua) sama rata, dan sesuai dengan norma hukum yang berlaku dengan mengutus salah seorang anggpta keluarganya untuk menemui tergugat untuk membicarakan pembagian harta bersamanya dengan penggugat dengan alasan-alasan yang tidak jelas ;

7) Bahwa sesuai ketentuan perundang-undangan yang berlaku. Setelah terjadi perceraian, maka harta yang diperoleh selama perkawinan, 1/2 (setengah) bagian menjadi hak tergugat ;

8) Bahwa tidak ada perjanjian pemisahan harta baik saat sebelum pernikahan maupun saat dilakukan pernikahan antara penggugat dan tergugat ;

9) Bahwa karena adanya kekhawatiran yang beralasan terhadap harta bersama yang merupakan obyek sengketa tersebut akan dialihkan/dipindah tangankan kepada orang lain, maka penggugat memohon agar di atas objek sengketa tersebut diletakan Sita Jaminan (Conservatoir Beslaag) ;

10) Bahwa oleh karena obyek sengketa merupakan harta bersama, maka demi hukum, putusan dalam perkara ini mohon dapat dilaksanakan terlebih dahulu (Uitvoorbaar bij voorrad) meskipun ada perlawanan, banding atau kasasi ;

11) Bahwa berdasarkan alasan di atas penggugat mohon kepada Ketua Pengadilan Agama Mataram Cq. Majelis Hakim yang menangani perkara ini untuk memanggil, memeriksa dan mengadili serta menjatuhkan purtusan yang amarnya.

Primer:

a) Menerima dan mengabulkan gugatan penggugat seluruhnya.

b) Melakukan sita marital (Marital beslag) terhadap semua harta bersama tersebut diatas.

c) Menyatakan hukum bahwa harta-harta yaitu:

(1) Tanah beserta bangunan dengan Sertifikat Hak Milik (SHM) atas nama tergugat yang terletak di kelurahan Pagesangan Barat Kecamatan Mataram, Kota Mataram, dengan batas-batas :

Sebelah Utara : Bapak Fahrudin

Sebelah Barat : Jalan/Bapak H. Taufik

Sebelah Selatan : Ibu Ida Azis

Sebelah Timur : Jalan/ Gang

(2) 1 (satu) unit kendaraan roda empat merk Toyota Kijang Super KF 40 Short tahun 1992 atas nama tergugat dengan Nomor Polisi DR 1340 WZ berwarna hitam,

(3) 1 (satu) unit kendaraan roda dua merek Honda Vario 125 type Honda NC $12 \mathrm{~A} 1 \mathrm{CF} \mathrm{A} / \mathrm{T}$ atas nama Tergugat dengan Nomor Polisi DR 5075 CG berwarna hitam, 
(4) 1 (satu) unit kendaraan roda dua merek Honda Beat type NC $11 \mathrm{BIC} \mathrm{A} / \mathrm{T}$ atas nama Tergugat dengan Nomor Polisi DR 6120 BI warna hitam,

Adalah harta bersama yang diperoleh penggugat dan tergugat selama perkawinan.

1. Menyatakan harta bersama penggugat dan tergugat dibagi dua;

2. Menghukum tergugat untuk menyerahkan apa yang menjadi hak dari penggugat atas harta bersama itu, yaitu sebagian dari harta bersama tersebut.

3. Menyatakan bahwa putusan ini dapat dijalankan lebih dahulu (uitvoerbaar bij vooraad) meskipun ada perlawanan, banding, atau kasasi.

4. Menghukum tergugat untuk membayar segala biaya yang timbul dalam perkara ini.

\section{Subsider :}

Apabila Majelis Hakim berpendapat lain mohon putusan yang seadil-adilnya.

Bahwa pada hari dan tanggal sidang yang telah ditetapkan, penggugat dan tergugat yang diwakili kuasa hukumnya masing-masing telah hadir dipersidangan dan Majelis Hakim telah mendamaikan penggugat dan tergugat akan tetapi tidak berhasil.

Bahwa penggugat dan tergugat telah pula menempuh proses mediasi dengan mediator Drs. $\mathrm{H}$. Muhammad Noor, S.H dan dari laporan mediator tanggal 29 April 2019, ternyata tidak berhasil mendamaikan penggugat dan tergugat;

Bahwa oleh karenanya usaha perdamaian penggugat dan tergugat tidak berhasil maka selanjutnya Majelis Hakim membacakan surat gugatan penggugat yang isinya tetap dipertahankan oleh penggugat dengan perbaikan gugatan tanggal 18 Maret 2019;

Bahwa terhadap gugatan penggugat tersebut, tergugat telah pula menyampaikan eksepsi dan jawaban tertanggal 15 juli 2019 sebagai berikut:

Berdasarkan uraian Putusan Pengadilan Agama Mataram di atas, hasil wawancara langsung dengan seorang Hakim di Pengadilan Agama Mataram, menyatakan:

"Dalam kasus diatas bahwa Hakim dalam melihat kasus perkara yang ada di Pengadilan Agama Mataram tersebut proses penyelesaian pembagian harta gono gini atau harta bersama yang dilakukan Hakim tidak berhasil, tetapi Hakim dalam proses pembagian harta bersama yaitu membagi harta bersama tersebut samasama 1/2 (seperdua) penggugat maupun tergugat karna memang didalam Pasal 37 Undangundang No 1 Tahun 1974 Tentang perkawinan tidak menegaskan berapa bagian masing-masing antara suami istri baik cerai mati atau cerai hidup, tetapi dalam Kompilasi Hukum Islam Pasal 96 dan 97 mengatur tentang pembagian harta gono gini baik cerai mati maupun cerai hidup yaitu masing-masing mendapat 1/2 (seperduaa) sepanjang tidak ditentukan dengan perjanjian perkawinan" (wawancara Hakim Pengadilan Agama Mataram, Tanggal 15 Juni 2020).

Berdasarkan kasus di Pengadilan Agama Mataram dan wawancara dengan Hakim bahwa proses pembagian harta gono gini atau harta bersama tersebut dibagi sama-sama $1 / 2$ (seperdua) suami dan $1 / 2$ (seperdua) istri.

\section{Pertimbangan Hakim Dalam Menentukan Pembagian Harta Gono Gini Suami-Istri Setelah Bercerai}

Adapun hasil pertimbangan Hakim dalam menentukan harta gono gini atau harta bersama suami istri setelah berceraian sebagai berikut :

a. Dalam Eksepsi

Menimbang, bahwa terhadap gugatan Penggugat tersebut, Tergugat melalui Kuasa Hukumnya telah mengajukan perlawanan (eksepsi) tentang gugatan cacat formil karena ketidak jelasan Penggugat dalam membuat surat gugatan mengenai dalil-dalil gugatan tidak disertai dengan dasar hukumnya.

Menimbang, bahwa selain diajukan perlawanan (eksepsi) tentang gugatan cacat formil, tergugat, juga mengajukan perlawanan (eksepsi) tentang gugatan kabur (obscuurlibel) karena adanya kesalahan, kekaburan penyebutan Nomor Akta Cerai antara Penggugat dan tergugat dalam surat gugatannya yakni menyebut akta cerai Nomor 502/AC/2009/PA.Mtr, sedangkan akta cerai penggugat dan tergugat terbit pada tahun 2018 dengan akta cerai Nomor 520/AC/2018PA.Mtr;

Menimbang, bahwa terlepas dari jawaban penggugat atas perlawanan (eksepsi) tersebut, Majelis Hakim menilai bahwa formulasi gugatan penggugat telah sesuai dengan peraturan perundang-undangan yang berlaku, karena penggugat telah menjelaskan di dalam gugatannya sebagaimana formalnya suatu gugatan yang memuat identitas para pihaknya, dalil-dalil tentang adanya hubungan hukum sebagai dasar tuntutan (fundamental petendi/posita) dan tuntutan (petitum) dan oleh karenanya gugatan penggugat ternyata terpenuhi formal suatu gugatan;

Menimbang, bahwa dalil perlawanan (eksepsi) yang menyatakan gugatan kabur karena adanya kesalahan dan ketidakjelasan penyebutan nomor akta cerai dalam gugatan penggugat, Menurut Majelis Hakim hal itu bukan menjadi alasan untuk perlawanan (eksepsi) tentang kaburnya suatu gugatan karena hal yang semacam itu hanyalah semata-mata kesalahan penulisan dan hal tersebut telah diperbaiki dengan adanya perubahan dan perbaikan gugatan, oleh karena Majelis Hakim berpendapat alasan perlawanan (eksepsi) tersebut haruslah dikesampingkan; 
Menimbang, bahwa berdasarkan pertimbangan tersebut diatas, maka perlawanan (eksepsi) tersebut tidak berdasarkan atas hukum, karenanya perlawanan (eksepsi) tersebut tidak berdasarkan atas hukum, karenaya perlawanan (eksepsi) tergugat haruslah ditolak;

\section{b. Dalam Pokok Perkara}

Menimbang, bahwa maksud dan tujuan gugatan penggugat adalah sebagaimana telah diuraikan diatas;

Menimbang, bahwa pada hari sidang yang telah ditetapkan, penggugat/kuasanya dan tergugat/kuasanya telah dating menghadap ke muka sidang;

Menimbang, bahwa Majelis Hakim dalam setiap persidangan telah berusaha mendamaikan para pihak namun tidak berhasil dan telah menempuh proses mediasi dengan mediator Drs. H.Muhammad Noor, S.H, sebagaimana laporan mediator tanggal 29 April 2019 akan tetapi tidak berhasil. Dengan demikian pemeriksaan perkara a quo telah memenuhi ketentuan Pasal 154 R.Bg. juncto Pasal 4 dan 7 Peraturan Mahkamah Agung Republik Indonesia Nomor 1 Tahun 2016 tentang Prosedur Mediasi di Pengadilan;

Menimbang, bahwa pada pokoknya penggugat mendalilkan sebagaimana diuraikan di bawah ini : 1) Bahwa antara penggugat dengan tergugat menikah pada tanggal 19 Oktober 1988 dan bercerai pada tanggal 10 Oktober 2018; 2) Bahwa selama dalam ikatan perkawinan penggugat dengan tergugat telah memperoleh harta-harta:

1) Sebidang tanah yang diatasnya berdiri bangunannya rumah permanen terletak di Jalan Serayu C No. 92 BTN Kekalik Baru Kelurahan Pagesangan Barat Kecamatan Mataram Kota Mataram;

2) 1 (satu) unit kendaraan roda empat (Mobil) Merk Toyota Kijang Super Tahun 1992, atas nama Tergugat, S.H. No. Pol. DR. 1340 WZ;

3) 1 (satu) unit kendaraan roda dua (Motor) Merk Honda Vario, atas nama Tergugat, S.H, No.Pol.: DR 5075 CG;

4) 1 (satu) unit kendaraan roda dua (Motor) Merk Honda Beat, atas nama Tergugat S.H, No. Pol. DR $6120 \mathrm{BI}$;

Bahwa penggugat mendalilkan harta-harta a quo adalah harta bersama antara penggugat dan tergugat karena diperoleh selama dalam perkawinan. Selanjutnya agar dibagi $1 / 2$ (setengah) bagian penggugat dan $1 / 2$ (setengah) bagian lagi untuk tergugat;

Menimbang, bahwa tergugat dalam jawabannya yang pada pokoknya mengakui adanya harta benda tersebut dalam gugatan penggugat poin 5.a sampai dengan 5.d sebagai harta bersama, namun tergugat menginginkan bahwa keseluruhan harta bersama tersebut tidak dibagi kepada penggugat dan tergugat akan tetapi diberikan kepada 3 (tiga) orang anaknya sebagai warisan atau peninggalan untuk mereka;
Menimbang, bahwa penggugat dalam replik (yang diajukan oleh penggugat) keberatan bahwa harta bersama tersebut untuk diberikan kepada ketiga orang anaknya dan harus terlebih dahulu harta bersama tersebut dibagikan kepada penggugat dan tergugat, sedangkan dalam dupliknya (yang diajukan oleh tergugat) tergugat tetap pada jawabannya dimana harta bersama tersebut diserahkan kepada anak-anak dan tidak perlu dibagi terlebih dahulu kepada penggugat dan tergugat;

Menimbang, bahwa setelah Majelis Hakim mempelajari dan mencermati dalil gugatan penggugat dan jawaban tergugat sebagaimana yang diuraikan di atas maka dapat diambil kesimpulan bahwa objek gugat sebagaimana dalam gugatan penggugat adalah benar harta bersama.penggugat dan tergugat karena tidak pernah dibantah oleh tergugat, hanya saja tergugat meminta agar harta tersebut diberikan kepada ketiga orang anak penggugat dan tergugat tanpa dibagi terlebih dahulu kepada penggugat dan tergugat;

Menimbang, bahwa karena harta tersebut dinilai adalah harta bersama penggugat dan tergugat yang tidak dibantah oleh tergugat, maka Majelis Hakim berpendapat tidak diperlukan adanya pembuktian baik dari penggugat maupun tergugat, akan tetapi karena penggugat dan tergugat telah mengajukan alat bukti surat dan alat bukti saksi, maka Majelis Hakim tetap akan mempertimbangkan alat-alat bukti dimaksud;

Menimbang, bahwa bukti P.1 dan P.2 berupa fotokopi salinan putusan pengadilan dan akta cerai, yang isiinya menerangkan bahwa penggugat dan tergugat telah menikah pada tanggal 19 Oktober 1988 dan bercerai pada tangga 10 Oktober 2018. Oleh karena itu Majelis Hakim berpendapat dan telah terbukti penggugat dan tergugat adalah suami isteri yang telah bercerai pada tanggal 10 Oktober 2018 dan telah dikaruniayai 3 (tiga) orang anak;

Menimbang bahwa alat bukti P.3 berupa Surat Pemberitahuan Pajak Terhutang Pajak Bumi dan Bangunan Tahun 2019 dan bila dihubungkan dengan alat bukti T.3, T.4 dan T.5 sebagaimaana yang diuraikan sebelumnya, maka alat bukti tersebut telah memberikan petunjuk bahwa obyek sengketa poin 5 .a berupa tanah dan bangunan rumah diperoleh pada tanggal 27 Juli 1995, dimana pada saat itu penggugat dan tergugat masih dalam ikatan perkawinan yang sah;

Menimbah bahwa alat bukti P.4 berupa Surat Penetapan Pajak Daerah PKB/BPNKB dan Jasa Raharja Tahun 2019 dan bila dihubungkan dengan alat bukti T.6, T.7 dan T.8, sebagaimana diuraikan di atas, maka alat bukti tersebut telah memberikan petunjuk bahwa objek sengketa poin 5.a berupa sebuah mobil kijang No. Pol. DR. $1340 \mathrm{WZ}$, atas nama tergugat diperoleh pada tahun 2012, dimana pada saat itu penggugat dan tergugat masih dalam ikatan perkawinan yang sah; 
Menimbang, bahwa alat bukti P.5 berupa surat Penetapan Pajak Daerah PKB/BPNKB dan Jasa Raharja Tahun 2019 dan bila dihubungkan dengan alat bukti T.10 dan T.11 sebagaimana diuraikan diatas, maka alat bukti tersebut telah memberikan petunjuk bahwa objek sengketa 5.c berupa 1 (satu) unit kendaraan roda dua, merk Honda Vario, No.Pol. DR. 5075 CG, atas nama tergugat diperoleh pada tahun 2014, dimana pada saat itu penggugat dan tergugat masih dalam ikatan perkawinan yang sah;

Menimbang, bahwa alat bukti P.6 berupa Surat Penetapan Pajak daerah PKB/BPNKB dan Jasa Raharja Tahun 2019dan bila dihubungkan dengan alat bukti T.1, maka alat bukti tersebut telah memberikan petunjuk bahwa objek sengketa poin 5 .d berupa 1 (satu) unit kendaraan roda dua, merk Honda Beat, No. Pol. DR $6120 \mathrm{BI}$, atas nama tergugat diperoleh dalam masa perkawinan penggugat dan tergugat;

Menimbang, bahwa disamping bukti surat tersebut, penggugat juga mengajukan 4 (empat) orang saksi untuk membuktikan dalil-dalil gugatannya sebagai berikut:

Menimbang, bahwa keempat orang saksi yang diajukan oleh penggugat telah memberikan keterangan dibawah sumpahnya dipersidangan dan keterangan yang disampaikannya adalah berdasarkan pengetahuan dan penglihatan sendiri, dan keterangannya relevan dan sesuai dengan pokok gugatan penggugat dimana saksi menyatakan bahwa penggugat dan tergugat selama dalam ikatan perkawinan telah memperoleh berupa harta : sebidang tanah yang di atasnya berdiri bangunan rumah permanen, sebuah mobil Toyota Kijang, dan sebuah sepeda motor merk Honda beat dan, sedangkan saksi kedua menyebutkan bahwa penggugat dan tergugat telah memperoleh harta berupa : sebidang tanah yang diatasnya berdiri bangunan rumah permanen, sebuah mobil Toyota Kijang, sebuah sepeda motor merk Honda vario, dan sebuah mobil sepeda motor N-Max dibeli oleh tergugat setelah bercerai, sedangkan saksi ketiga dan saksi keempat telah menerangkan penggugat dan tergugat selama dalam ikatan perkawinan yang sah telah memperoleh harta berupa sebidang tanah yang diatasnya berdiri bangunan rumah permanen, sebuah mobil Toyota Kijang, sebuah sepeda motor merk Honda Vario, dan sebuah sepeda motor Beat;

Menimbang, bahwa tergugat dalam persidangan telah mengajukan 4 (empat) orang saksi dimana saksi satu, saksi ketiga bernama Harun, S.Pd Bin H.Amin dan saksi keempat sama-sama menerangkan bahwa penggugat dan tergugat selama dalam ikatan perkawinan yang sah telah memperoleh harta berupa tanah yang diatas berdiri sebuah bangunan permanen, sebuah mobil Toyota Kijang, sebuah sepeda motor Merk Honda Vario, dan sebuah sepeda motor Merk Beat, akan tetapi sepeda Honda beat tersebut telah dijual oleh tergugat setelah bercerai dengan penggugat dan hasil penjualannya menurut tergugat dipergunakan untuk membeli sebuah sepeda motor merk Yamaha N-Max, sedangkan saksi 2 tergugat hanya menerangkan tentang adanya hutang tergugat sejumlah Rp. 25.000.00o, pada tahun 2014 dan hutang tersebut dipergunakan untuk tambahan pembelian 1 (satu) unit kendaraan Roda 4 Merk Toyota Kijang sebagaimana diuraikan diatas;

Menimbang, bahwa apabila Majelis Hakim mempelajari alat bukti surat dengan alat bukti saksi baik yang diajukan oleh penggugat maupun yang diajukan oleh tergugat, maka dapat disimpulkan bahwa obyek gugatan poin 5 . a berupa tanah yang diatasnya berdiri bangunan permanen, obyek gigatan poin 5.b berupa sebuah kendaraan roda 4 merk Toyota kijang, obyek gugatan poin. $5 \mathrm{c}$ berupa sebuah motor Honda vario dan obyek gugatan poin 5.d berupa sebuah sepeda motor merk Honda beat adalah harta yang diperoleh secara bersama-sama oleh penggugat dan tergugat selama dalam ikatan perkawinan keduanya, meskipun ada saksi dari tergugat yang menyatakan obyek gugatan poin $5 . \mathrm{d}$ telah dijual oleh tergugat setelah penggugat dan istri bercerai dan hasilnya penjualannya dipergunakan untuk membeli sebuah motor Yamaha N-Max yang sekarang dikuasai oleh tergugat.;

Menimbang, bahwa untuk menentukan harta bersama penggugat dan tergugat Majelis Hakim perlu mendasarkan pertimbangannya pada Pasal 35 Undangundang Nomor Tahun 1974 yang menyebutkan "Harta benda yang diperoleh selama perkawinan menjadi harta benda bersama" dan Pasal 1 huruf (f) Kompilasi Hukum Islam menyebutkan "Harta kekayaan dalam perkawinan atau syirkah adalah harta yang diperoleh baik sendirisendiri atau bersama suami isteri selama dalam ikatan perkawinan berlangsung dan selanjutnya disebut harta bersama tanpa mempersoalkan terdaftar atas nama siapapun", dari kedua Pasal tersebut dapat difahami bahwa harta bersama yang diperoleh suami istri dalam ikatan perkawinan yang sah maka itu menjadi harta bersama suami isteri dalam ikatan perkawinan yang sah maka itu menjadi harta bersama suaami isteri tersebut tanpa memperoleh terdaftar atas nama siapapun;

Menimbang, bahwa apabila Majelis Hakim menghubungkan dalil gugatan penggugat yang tidak dibantah oleh tergugat dengan alat bukti yang masingmasing diajukan penggugat dan tergugat dalam persidangan dan ketentuan hukum sebagaimana pertimbangan diatas, maka Majelis Hakim dapat menilai dan berpendapat bahwa obyek sengketa sebagaimana yang didalilkan oleh penggugat telah didukung oleh 2 (dua) alat bukti yang sah sehingga gugatan penggugat dinyatakan telah terbukti, oleh karena obyek-obyek tersebut ditetapkan sebagai harta bersama penggugat dan tergugat. Dengan demikian gugatan penggugat pada gugatan (petitum) angka 2 (dua) sudah sepatutnya untuk dikabulkan.;

Menimbang, bahwa oleh karena gugatan (petitum) angka 2. (dua) telah dikabulkan sebagaimana 
pertimbangan diatas, maka Majleis Hakim dapat menetapkan harta bersama penggugat deng tergugat adalah sebagai berikut;

1) Tanah beserta bengunan seluas $71 \mathrm{M} 2$, dengan sertipikat Hak Milik (SHM) atas tergugat yang terletak di jalan Serayu C No. 92 RT/RW 011/067 BTN Kekalik Baru, Kelurahan Pagesangan Barat Kecamatan Mataram, Kota Mataram, dengan batas-batas :

Sebelah Utara : Bapak Fahrudin

Sebelah Barat : Jalan/Bapak H. Taufik

Sebelah Selatan : Ibu Ida Azis

Sebelah Timur : Jalan/Gang

2) 1 unit kendaran roda empat merk Toyota kijang Super KF 40 Short tahun 1992 atas nama tergugat dengan nomor polisi DR $1340 \mathrm{WZ}$ berwarna hitam,

3) 1 unit kendaraan roda dua merk Honda vario 125 type Honda NC 12 A ICF A/T atas nama tergugat dengan nomor polisi DR 5075 CG berwarna hitam,

4) 1 unit kendaraan roda dua merk Honda Honda beat type $\mathrm{NC} 11 \mathrm{BIC} \mathrm{A/T}$ atas nama tergugat dengan nomor polisi DR 6120 BI warna hitam,

Menimbang, bahwa oleh karena harta bersama telah dapat ditetapkan maka Majelis Hakim akan mempertimbangkan dan menjawab tuntutan (petitum) angka 3 (tiga) meminta agar harta bersama dibagi antara penggugat dan tergugat dan dalam hal ini Majelis Hakim akan mempertimbangkan ketentuan Pasal 97 Kompilasi Hukum Islam yang berbunyi "janda atau duda cerai hidup masing-masing berhak seperdua dari harta bersama sepanjang tidak ditentukan lain dalam perjanjian perkawinan;

Menimbang, bahwa setelah majelis Hakim memperhatikan alat bukti P.1 dan T.1 yang masingmasing diajukan oleh penggugat dan tergugat tidak terbukti adanya perjanjian perkawinan antara penggugat dengan tergugat sehingga dengan demikian dalam hal pembagian harta bersama penggugat dengan tergugat berlaku dan dapat diterapkan ketentuan bahwa bila janda dan duda cerai hidup, maka masing-masing penggugat dan tergugat mendapatkan seperdua dari harta bersama sebagaimana dipertimbangkan diatas dan oleh karenanya Majelis Hakim dapat menetapkan dimana masing-masing penggugat dan tergugat mendapatkan seperdua dari harta bersama tersebut diatas, sehingga dengan demikian tuntutan (petitum) angka 3 (tiga) gugatan penggugat dapat dikabulkan;

Menimbang, bahwa untuk adanya suatu putusan yang dimiliki tite atau kekuatan ekskutorial dan untuk menjamin terlaksananya pembagian harta bersama tersebut sebagaimana pertimbangan diatas, maka Majelis Hakim perlu menetapkan menghukum tergugat untuk menyerahkan bagian penggugat sebagaimana pertimbangan sebelumnya secara aman tanpa syarat;
Menimbang, bahwa sehubungan dengan adanya keterangan saksi satu, tiga dan empat yang diajukan oleh tergugat dan pengakuan tergugat sendiri yang menyebutkan bahwa obyek 5.d berupa satu unit sepeda motor merk beat telah dijual oleh tergugat setelah penggugat dan tergugat bercerai, namun tidak disebutkan berapa nilai jualnya dan apabila hal itu benar terjadi maka Majelis Hakim berpendapat bahwa obyek 5.d tersebut dapat diperhitungkan sebagai bagian untuk tergugat pada saat pembagiannya nanti;

Menimbang, bahwa dalam jawaban menyatakan bahwa penggugat dan tergugat memiliki hutang bersama berupa uang sejumlah Rp. 25.000.0000.- kepada Fetra Azimin sebagaimana bukti T.9 akan tetapi tergugat tidak secara tegas apakah itu jawaban dari gugatan penggugat atau gugat balik (Rekonvensi), sedangkan penggugat membantah adanya hutang tersebut akan menurut Majelis Hakim seharusnya tergugat menyatakan secara tegas jawabannya dimana hutang tersebut dikategorikan sebagai gugatan Rekonvensi dari tergugat, akan tetapi tergugat tidak menformulasikan gugatan Rekonvensi, sehingga dalil yang diajukan oleh tergugat tersebut tidak perlu dipertimbangkan dan harus dikesampingkan;

Menimbang, bahwa karena jawaban tergugat tersebut tidak secara tegas menyatakan sebagai gugatan Rekonvensi maka Majelis Hakim berpendapat dalil bantahan semacam itu tidak dapat diterima bilamana tergugat tidak memformulasikan sebagai gugatan balik (Rekonvensi) tentang adanya hutang tersebut, sehingga dengan demikian dalil bantahan yang menyatakan adanya hutang bersama dalam memperoleh harta-harta sebagaimana dalam jawaban tergugat dan alat bukti yang diajukan berkenaan dengan hutang tersebut (bukti T.9) tidak perlu dipertimbangkan lagi;

Menimbang, bahwa tergugat dalam jawabannya menyatakan bahwa harta bersama tidak perlu dibagi kepada penggugat dan tergugat mengingat penggugat dan tergugat telah memiliki 3 (tiga) orang anak dan menurut tergugat harta-harta tersebut lebih layak untuk diberikan kepada anak-anak bukan dibagi kepada penggugat dan tergugat, sedangkan penggugat tidak menyetujui hal tersebut, dan Majelis Hakim menilai permintaan tergugat untuk menyerahkan obyek sengketa tersebut kepada ketiga orang anak adalah tidak tepat karena menurut Majelis Hakim harta bersama antara penggugat dan tergugat mutlak menjadi hak penggugat dan tergugat dan belum timbul hak waris, dari para ahli waris karena penggugat dan tergugat masih hidup, oleh karena itu Majelis Hakim berpendapat permohonan tergugat tersebut patut dikesampingkan;

Menimbang, bahwa berdasarkan permohonan sita jaminan oleh penggugat dalam tuntutan (petitum) poin ke 4 yang telah ditangguhkan oleh Majelis Hakim bersamaan dengan menetapkan hari sidang karfena selama persidangan berjalan tidak ada tanda-tanda 
pengalihan/pemindahantanganan atas obyek sengketa sehingga Majelis Hakim berpendapat pemohonan tersebut tidak beralasan dan harus ditolak;

Menimbang, bahwa terhadap petitum gugatan poin ke 5 yang meminta putusan dilaksanakan terlebih dahulu (Uitvoorbaar bij vooraad) meskipun perlawanan, banding atau kasasi, Majelis Hakim mempertimbangkan bahwa untuk dapat terpenuhi tuntutan diatas, harus ada alasan-alasan dan bukti yang sangat kuat untuk dapat dikabulkan yuntutan tersebut, missal tergugat berkelakuan buruk atau beriktikad buruk dan hal inipun terlebih dahulu harus ada persetujuan dari Pengadilan Tingkat Banding dan Mahkamah Agung, sehingga tuntutan tersebut harus dinyatakan ditolak;

Menimbang, bahwa terhadap tuntutan penggugat poin 7 , agar tergugat dihukum untuk membayar biaya perkara ini, Majelis Hakim mempertimbangkan bahwa oleh karena perkara ini adalah termasuk dalam bidang perkawinan, maka berdasarkan Pasal 89 Ayat (1) dan Pasal 90 Ayat (1) Undang-undang Nomor 7 Tahun 1989 semua biaya perkara timbul dalam perkara ini dibebankan kepada penggugat untuk membayarnya;

Menimbang, bahwa berdasarkan dari uraian pertimbangan-pertimbangan tersebut diatas, maka gugatan penggugat dikabulkan sebagian dan menolak selain dan selebihnya;

Mengingat, segala ketentuan perundang-undangan yang berlaku dan ketentuan hukum islam yang berkaitan dengan perkara:

Adapun pertimbangan Hakim dalam menentukan pembagian harta gono gini atau harta bersama yaitu: a) Hakim menanyakan terlebih dahulu terhadap Penggugat dan Tergugat apakah harta yang diajukan adalah harta bersama atau tidak, bisa saja di dalam adanya ikatan tali pernikahan itu harta bawaan dari masing-masing pihak dan bisa saja perolehan harta tersebut di peroleh dalam usaha bersama. b) Apabila harta tersebut sudah terbukti harta bersama suami istri itu maka pembagiannya berdasarkan undang-undang yaitu $1 / 2$ (satu seperdua) tetapi hakim juga bisa berpendapat berdasarkan rasa keadilan dan melihat kondisi Penggugat dan Tergugat. Misalnya salah satu contoh siapa yang bekerja dan berperan banyak dalam memperoleh harta itu maka yang mendapat bagian yang lebih besar sedangkan apabila seorang istri yang bekerja mencari nafkah lalu suaminya tidak bekerja maka pembagian perolehan harta tersebut lebih besar ke istri, sebab seharusnya suami yang harus menafkahi istri tetapi sebaliknya istri yang mencari nafkah dan menjadi tulang punggung kelurga.

\section{TEMUAN ATAU DISKUSI}

1. Tugas Hakim di Pengadilan Agama

Tugas Hakim di Pengadilan Agama adalah menerima perkara, memeriksa perkara, mengadili perkara serta menyelesaikan perkara yang diajukan kepadanya.
Menerima perkara, perkara yang diterima oleh hakim merupakan sengketa perdata berupa pembagian harta warisan, perceraian dan lainnya. Khusus penyelesaian harta gono-gini suami istri setelah perceraian pada dasarnya harus terdaftar dibagian administrasi untuk mendapatkan nomor registrasi persidangan, sehingga dengan demikian dapat dilanjutkan pada tahap berikutnya.

Memeriksa perkara, perkara yang diperiksa merupakan tahapan kedua, dimana dalam tahapan ini merupakan pembuktian berkas perkara baik bukti materil maupun bukti fisik. Apabila kedua bukti tersebut dinyatakan benar berdasarkan ketentuan undangundang dan aturan berlaku maka perkara dapat dilanjutkan pada tahapan berikutnya, namun sebaliknya apa bila pembuktian tidak mencukupi maka perkara bisa dihentikan, dan dinyatakan selesai.

Mengadili perkara, dalam memberikan keputusan hakim memiliki beberapa pertimbangan asas hukum yakni asas kemanfaatan, keterbukaan, keadilan dan penegakan hukum untuk kedua pihak. Hakim dalam memeriksa dan mengadili bebas untuk menentukan sendiri cara-cara memeriksa dan mengadili, kebebasan hakim bermakna kebebasan dalam konteks kebebasan lembaga peradilan. Konsekwensi logisnya harus dimaknai bahwa baik secara umum maupun dalam perkara-perkara tertentu, pimpinan pengadilan dapat memberikan arahan atau bimbingan bagi para hakim yang bersifat nasihat atau petunjuk, hal ini tidak mengurangi makna kebebasan hakim.[12]

Tahap terakhir memberikan keputusan penyelesaian perkara kedua pihak, dalam pemberian keputusan ini hakim dengan sungguh-sungguh memberikan keputusan yang bijaksana agar kedua pihak yang bersengketa ini dapat menerima dengan baik misalnya pembagian sama rata harta gono-gini seperti $1 / 2$ (satu seperdua) tetapi hakim juga bisa berpendapat berdasarkan rasa keadilan dan melihat kondisi Penggugat dan Tergugat.

Disamping itu juga, peran hakim dalam menangani kasus harta gono gini atau harta bersama yaitu hakim harus mencerminkan kepastian hukum yang harus diselesaikan dalam proses penyelesaian perkara dalam persidangan memiliki peran untuk mendapatkan kepastian hukum yang tepat sehingga eksistensinya semakin diakui dan kesiapannya semakin matang.

Penyelesaian harta gono-gini tersebut sejalan dnegan pendapat bahwa penyelesaian sengketa harta gonogini di Pengadilan Agama adalah bentuk penyelesaian sengketa secara litigasi (di dalam Pengadilan) sesuai dengan kompetensi atau yurisdiksi mutlak Pengadilan Agama, yakni dalam bidang kewarisan, misalnya penentuan dan pembagianharta warisan di antara para ahli waris. Sengketa kewarisan karena kematian Pewaris, yang terjadi di antara anak kandung sebagai Penggugat dan Ibu Tiri sebagai Tergugat yang telah menerapkan/mengimplementasikan 
ketentuan-ketentuan hukum dan peraturan perundangundangan yang berlaku.[13] Pertimbangan Hakim dalam memutuskan perkara mengacu Pasal 35 ayat (1) Undang-Undang Nomor 1 Tahun 1974 dan Pasal 97 Kompilasi Hukum Islam. Harta bersama (Gono gini) yang diperoleh selama masa perkawinan baik itu menurut Fiqh dan Undang-undang sama.[14];[15];

2. Tugas panitera di Pengadilan Agama Mataram

Tugas panitera di Pengadilan Agama Mataram adalah melaksanakan administrasi perkara, dan untuk mencatat jalannya persidangan sampai proses jalan persidangan berakhir. Sedangkan peran panitera tidak dapat dipisahkan dari tugas pokok pengadilan itu sendiri karna memang peran tugas panitera itu sendiri tidak dapat berjalan secara efektif apabila tugas pokok tersebut tidak berjalan dengan baik.

Proses pengaturan pembagian harta gono gini atau harta bersama diakui secara hukum baik secara kepengurusan, penggunaannya, serta pembagiannya. Ketentuan harta gono gini atau harta bersama juga sudah diatur dalam Pasal 35 UU No. 1 Tahun 1974 Tentang Perkawinan, Pasal 119 KUH Perdata dan Pasal 85 dan 86 Kompilasi Hukum Islam. Untuk menegakkan keadilan, hakim mempertimbangkan bunyi Pasal 35 ayat (1) Undang-Undang Nomor 1 Tahun 1974 dan Pasal 97 Kompilasi Hukum Islam sebagai pedoman utama dalam memberikan keputusan. Karena harta bersama (Gono gini) yang diperoleh selama masa perkawinan baik itu menurut Fiqh dan Undang-undang sama merupakan harta bersama.[16];[17]

Dalam kasus diatas bahwa penulis dalam melihat kasus perkara yang ada di Pengadilan Agama Mataram tersebut proses penyelesaian pembagian harta gono gini atau harta bersama yang dilakukan Hakim tidak berhasil, tetapi Hakim dalam proses pembagian harta bersama yaitu membagi harta bersama tersebut sama-sama $1 / 2$ (seperdua) penggugat maupun tergugat karna memang didalam Pasal 35-37 Undang-undang No 1 Tahun 1974 Tentang perkawinan tidak menegaskan berapa bagian masing-masing antara suami istri baik cerai mati atau cerai hidup, tetapi dalam Kompilasi Hukum Islam Pasal 96 dan 97 mengatur tentang pembagian harta gono gini baik cerai mati maupun cerai hidup yaitu masing-masing mendapat $1 / 2$ (seperduaa) sepanjang tidak ditentukan dengan perjanjian perkawinan., dan pertimbangan hakim dalam menyelesaikan kasus harta gono gini atau harta bersama tersebut tidak mesti terpaku terhadap UU tetapi sebagai hakim proses pertimbangan pembagian harta gono gini harus berdasarkan rasa keadilan karna hakim sendiri mempunyai asas kontralegen didalam memutus suatu perkara karena memang tugas dari hakim itu sendiri yaitu memeriksa, memutus dan menyelesaikan suatu perkara.

\section{E. SIMPULAN DAN SARAN}

Berdasarkan hasil penelitian di Pengadilan Agama Mataram Tugas dan Peran Pengadilan Agama dalam menangani setiap perkara tidak terlepas dari aturan Undang-undang yang sudah ada karena memang disetiap lembaga instansi yang akan melakukan tugasnya dan perannya sudah diatur oleh undangundang yang berlaku dan apabila mereka tidak melakukannya dengan berdasarkan aturan undangundang maka akan dikenakan sangksi hukum, sedangkan Penyelesaian sengketa pembagian harta gono gini atau harta bersama yang di lakukan di Pengadilan Agama Mataram ada dua cara yaitu pelaksanaan pengajuan gugatan perceraian dimulai dengan pengajuan gugatan oleh salah satu pihak, dan syaratsyarat pengajuan yang terpenuhi maka proses pembagian harta gono gini atau harta bersama diperoses sesuai dengan peraturan perundang-undangan yang berlaku. Maka putusan pengadilan agama mataram menetapkan pembagian harta gono gini penggugat mendapatkan 1/2 (satu seperdua). Dan pertimbangan pembagian harta gono gini atau harta bersama tidak mesti terpaku terhadap UU tetapi sebagai hakim proses pertimbangan pembagian harta gono gini harus berdasarkan rasa keadilan karna hakim sendiri mempunyai asas kontralegen didalam memutus suatu perkara karena memang tugas dari hakim itu sendiri yaitu memeriksa, memutus dan menyelesaikan suatu perkara.

Dengan demikian menyarankan kepada Hakim, dalam menjalankan tugas dan perannya harus bersikap adil dalam memutus suatu perkara karna memang hakim sangat diutamakan keadilan distributif dalam memutus pembagian harta gono gini atau harta bersama dan harus mencermati lebih seksama dalam menilai dan menafsirkan Undang-undang.

Panitera, dalam menyelesaikan proses administrasi perkara serta mencatat proses jalannya persidangan harus dengan lebih teliti dan hati-hati dalam memeriksa kasus yang sedang diajukan. Masyarakat, agar berhatihati dalam memilih pasangan sebab apabila tidak berhati-hati dalam memilih pasangan akan mengakibatkan percerain dan menimbulkan perebutan harta gono gini atau harta bersama.

\section{UCAPAN TERIMA KASIH}

Penulis mengucapkan terima kasih kepada semua pihak yang terlibat dalam penelitian yang senantiasa memberikan dukungan material, moril dan semangat kepada penulis sehingga artikel ini selesai dengan baik.

\section{DAFTAR RUJUKAN}

[1] M. Hanifah, "Perkawinan Beda Agama Ditinjau dari Undang-undang Nomor 1 Tahun 1974 Tentang Perkawinan," Soumatera Law Rev., vol. 2, no. 2, pp. 297-308, 2019.

[2] T. Subekti, "Sahnya Perkawinan Menurut Undang- 
Undang Nomor 1 Tahun 1974 Tentang Perkawinan Ditinjau Dari Hukum Perjanjian,” J. Din. Huk., vol. 10, no. 3, pp. 329-338, 2010.

[3] B. Nagara, "Pembagian Harta Gono-Gini atau Harta Bersama Setelah Perceraian Menurut Undang-Undang Nomor 1 Tahun 1974," Lex Crim., vol. 5, no. 7, 2016.

[4] E. C. Singal, "Pembagian Harta Gono-Gini Dan Penetapan Hak Asuh Anak Akibat Perceraian Berdasarkan Undang-undang Nomor 1 Tahun 1974," Lex Crim., vol. 6, no. 5, 2017.

[5] E. Rochaeti, "Analisis Yuridis Tentang Harta Bersama (Gono Gini) Dalam Perkawinan Menurut Pandangan Hukum Islam dan Hukum Positif," J. Wawasan Yuridika, vol. 28, no. 1, pp. 650-661, 2015.

[6] M. T. Pradoto, "Aspek Yuridis Pembagian Harta Bersama Dalam Perkawinan (Tinjauan Hukum Islam Dan Hukum Perdata)," J. Jurisprud., vol. 4, no. 2, pp. 85-91, 2017.

[7] U. Siti Urwatul, “Tugas Dan Peran Pengadilan Agama dalam Menyelesaikan Kasus Harta Gono Gini Sebagai Upaya Penyelesaian Konflik Keluarga Pasca Bercerai Suami Istri (Studi Kasus di Pengadilan Agama Mataram).” UNIVERSITAS MUHAMMADIYAH MATARAM, 2020.

[8] H. Susanto, Pembagian Harta Gono-Gini Saat Terjadi Perceraian. VisiMedia, 2008.

[9] A. Van Bone, "Penyelesaian Sengketa Harta Bersama Berstatus Agunan dalam Perkara Perceraian di Pengadilan Negeri," Lex Adm., vol. 5, no. 5, 2017.

[10] Indonesia, Undang-undang perkawinan. Pustaka Widyatama, 2004.

[11] PTA Mataram, "Tingginya Angka Perceraianan," Pengadilan Tinggi Agama Mataram, 2020.

[12] F. F. Adonara, "Prinsip Kebebasan Hakim Dalam Memutus Perkara Sebagai Amanat Konstitusi," $J$. Konstitusi, vol. 12, no. 2, pp. 217-236, 2016.

[13] S. F. Tanjung, "Penyelesaian Sengketa Harta Gono Gini Pada Pengadilan Agama Kotamobagu (Studi Kasus Putusan No. 738/Pdt. G/2014/PA. Ktg)," LEX Soc., vol. 6, no. 7, 2018.

[14] R. Rahmanda, "Analisis Pertimbangan Hakim Pengadilan Agama Curup Tentang Harta Gono Gini (studi putusan no. 474/pdt. g/2017/pa. crp).” IAIN Curup, 2018.

[15] A. Haryanti, "Penyelesaian Sengketa Pembatalan Pernikahan Karena Adanya Penipuan Status Istri," $J$. Pendidik. Kewarganegaraan, vol. 4, no. 2, pp. 121-134, 2017.

[16] A. Gunawan, "Mencari Keadilan Sengketa Harta GonoGini (Telaah Perspektif Hukum Islam dan Hukum Positif)," J. YUSTITIA, vol. 18, no. 1, 2019.

[17] K. Kamarusdiana and D. AlFaruqi, "Konsep Hukum Penyelesaian Sengketa Harta Bersama di Indonesia (Analisis Perkara No. 195/Pdt. 2013/PA. Mtr, Putusan No. 04/Pdt. G/2014/PTA. Mtr, dan Putusan No. 629 $\mathrm{K} / \mathrm{Ag} / 2014)$," J. INDO-ISLAMIKA, vol. 6, no. 2, pp. 263-292, 2016. 